\title{
Green and Lean Sustainable Development Path in China: Guanxi, Practices and Performance
}

\begin{abstract}
Globalisation has created both drivers and pressure for Chinese organisations to enhance their business performance as well as environmental performance. Green and lean practice is emerging as a critical approach for Chinese organisations to achieve sustainable development and improve organisational performance. By conducting empirical studies from 172 respondents on green and lean practice in different Chinese organisations, this research shows how green and lean practice affects organisational performance and how this association is affected by guanxi. The findings explain that guanxi between organisational partners improves the positive effect of green and lean practice on organisational performance. The results of this paper offer helpful insights into how managers should enhance their guanxi initiatives, in order to improve environmental and business performance over their supply chains. The paper also suggests the limitations of this research, as well as directions for future research.

http://dx.doi.org/10.1016/j.resconrec.2016.02.006
\end{abstract}

Keywords: Green and lean practice; environmental performance; guanxi; business performance; Chinese organisations; Sustainable development

\subsection{INTRODUCTION}

Sustainable development and environmental protection are the themes of the day. According to Mckinsey (2010), for most companies environmental issues have become a significant topic. Bai et al. (2015) point out that balancing environmental and economic performance has become more and more significant for organisations facing regulatory, competitive and community pressures. Success in fulfilling environmental concerns may offer new chances to create value to key business programmes as well as great opportunities for competition in today's rapidly changing business environment (Kurdve et al., 2014; Tseng, 2014b; Shen et al., 2013; Tseng et al., 2015).

As the largest developing country with the fastest-growing economy, the environmental issues have become even more striking in China (Zhu et al., 2005). Economy (2007) indicates that the acceptances of China into the WTO and its recent dramatic 
economic growth have been accompanied by serious deterioration of the environment. In order for China to continue its rapid economic development, Chinese organisations need to initiate industrial and corporate environmental management measures (Tseng and Chiu, 2013; Bai et al., 2015). Since 1992, China has incorporated sustainable development within a basic national strategy and many Chinese manufactures have started implementing organisational approaches such as environmental management systems and cleaner production, along with green production to improve both environmental and economic performance (He et al., 2012; Zhu et al., 2005; Tseng, 2014a). However, ecological degradation and environmental pollution in China have continued to be serious issues and have inflicted great damage on the quality of life and economy. For many reasons the implementation of green practices measures by Chinese organisations faces severe challenges (Chow, 2008). Limited knowledge of the availability and benefits of green methods of production, for instance, leads many managers to see 'being green' as an incremental cost rather than a potential benefit, and they may not understand how their use of conventional alternatives impacts the environment. Therefore, how can Chinese firms overcome the challenges of greening their supply chain? Lean manufacturing was initially developed in Japan, by Toyota (Herron and Hicks, 2008). Since then, it has been adopted in a wide range of industries all around the word (Garza-Reyes et al., 2012). Nowadays, lean manufacturing is considered the most influential new paradigm in manufacturing. In essence, it involves reducing inventories and lead-times, and improving productivity and quality (Forrester et al., 2010; Abdul Wahab et al., 2013). However, in order to respond to the growth of customer requirements for goods and services that comply with government environmental regulations, organisations have been forced to rethink how they manage their operations and processes. In this context, not only is the lean paradigm in line with organisational objectives such as profitability and customer satisfaction, but it is also being used to overcome green challenges and to improve environmental performance (Govindan et al., 2015).

Green and lean practices have been adopted by organisations in order to achieve more environmentally sound operations and to manage their relationships with suppliers in the context of supply chain management (Vais et al., 2005; Azevedo et al., 2012; Kurdve et al., 2014). The lean paradigm is perceived to reduce waste (and consequently to reduce costs), to improve quality and productivity, to ensure better use of resources and to deliver value to customers (EPA, 2007; Pakdil and Leonard, 2014). The green paradigm seeks to lower negative environmental impacts and environmental risks while eliminating waste and improving ecological efficiency (Muduli, et al., 2013; Zhu et al., 2005; Tseng and Chiu, 
2015). When green and lean practices are combined, it is important to identify which of them are relevant to any particular set of operations and which require improvement (Duarte and Cruz-Machado, 2013; 2015). A number of studies have considered the relationship and investigated the effects of green and lean initiatives on organisational performance and their integration as a single combined approach (Larson and Greenwood, 2004; Dues et al., 2013; Wiengarten et al., 2013; Duarte and Cruz-Machado, 2015; Sobral et al., 2013; Garza-Reyes, 2015; Mollenkopf et al., 2010; Pampanelli et al., 2014; Mason et al., 2008; Kurdve et al., 2014). However, despite these studies, the academic literature and research exploring the impact of green and lean practice on organisational performance still remain in their early stages. In particular, no systematic study has been undertaken to identify those key green and lean practices that might make the difference between success and failure in green and lean implementation. Production managers need to understand these green and lean practices in order to be able to strategically manage their environmental and business performance.

Additionally, other organisational practices can potentially moderate the relationship between green and lean practice and organisational performance. This paper looks specifically at one such organisational practice: guanxi. Guanxi is deeply rooted in 5000 years of Chinese culture. It may work as a moderator that influences the relationship between green and lean practice and performance. Therefore, the existence or non-existence of guanxi may hinder or help the green and lean practices performance implications. According to Wong (2007), guanxi plays a vital part in Chinese organisations. It has important implications for inter-organisational and inter-personal dynamics in Chinese society and can therefore significantly affect the resources available to a firm, and its interaction with the task environment (Kao, 1993). As a result, researchers and businesses have sought to examine the roles that green and lean practice, organisational performance and guanxi play in Chinese organisations, with a view to offering useful insights into how effective implementation of green and lean practices can be improved, in order to enhance environmental and business performance.

Due to the increasingly discussions concerning climate change, organisations in developing countries such as Indonesia, Malaysia, Philippines and China find themselves facing increased pressure from government and customers to do business in an environmentally responsible manner, which generally requires extra investment (Tan et al., 2014). Although many researchers point out that green and lean practice can be a catalyst for organisations to improve their environmental and business performance, the hesitation over the green and lean practice is fuelled by the fact that there is confusion about: 
(1) What green and lean practices are?

(2) How green and lean practices can result in better organisational performance?

This paper contributes to green and lean practice by providing a cross-sectional, largesample measurement model to test the effectiveness of developed green and lean practices in improving Chinese organisations' environmental and business performance. Also, it shows that the different level of performance improvement is dependent on guanxi utilisation in Chinese organisations. It tests specific hypotheses, based on literature and empirical study. This paper differs from the vast majority of the green and lean literature, which focuses on the serial or simultaneous deployment of green and lean practice, this research uses the actual experience of Chinese organisations to explain relationships between green and lean practice and organisational performance. Additionally, the study finds that guanxi can encourage the preference to build relationships to enhance organisational performance.

\subsection{THEORETICAL BACKGROUND}

The literature on green and lean practice has been growing in recent years. Different aspects of green and lean paradigms have been studied; in particular, studies have examined whether the sequential or simultaneous deployment of these practices best aligns the two approaches (Diaz-Elsayed et al., 2013; Pampanelli et al., 2014; Dues et al., 2013).

In this research, we identify five sets of green and lean practices designed to achieve better organisational performance (see Table 1). These practices were developed from literature that addressed various aspects of green and lean practices, as well as input from experts, enterprises and officials involved in environmental management. First, the mindsets and attitudes of people operating a green and lean system are fundamental. Green and lean is not only about changing things, but about changing how people think. The green and lean way of thinking often runs counter the prevailing mindset: for example, it argues that organisations should think small and flexible rather than thinking big, and that problems create opportunities to improve rather than necessitating blame (Jeyaraman and Teo, 2010). Second, strong, committed leadership is essential for successful implementation of green and lean practices, which must be driven from the top down. In a green and lean environment, leadership is about defining the values and goals of the organisation and developing strategy (Bergmiller and McCright, 2009). Literature shows that the difference between green and lean success and failure starts with leadership (Rothenberg et al., 2001). Third, employee involvement can assist green and lean practice in different ways, with key factors including their attitude, experience, knowledge, skills, thinking of enterprises, customer consciousness, 
initiative taking, adaptation, commitment, influence, collaborative skills and discipline (Florida, 1996; Unnikrishnan and Hedge, 2006). Fourth, Drew et al. (2004), clearly state that the effectiveness of the green and lean operating system depends on adopting an integrated approach. Green and lean should therefore be seen as a integrated, comprehensive management pattern and philosophy of manufacturing that must be consistently practised throughout an organisation. Finally, it is easy to see how many benefits - increasing product quality, smaller inventories and a shorter payback period - can be achieved by increasing understanding about green and lean tools and techniques, and using them appropriately (Hines et al., 2004; Srivastava, 2007). Therefore, tools and techniques should be considered as a part of critical green and lean practice in organisations.

Table 1: Green and lean practices

\begin{tabular}{ll}
\hline Green and Lean Practice & Literature Support \\
\hline Mindset and Attitude & (Jeyaraman and Teo, 2010; Dues et al., 2013; Wiengarten et al., \\
& 2013; Azevedo et al., 2012) \\
Leadership and Management & (Bergmiller and McCright, 2009; Rothenberg et al., 2001; Sobral et \\
& al., 2013; Larson and Greenwood, 2004) \\
& (Florida, 1996; Zhu et al., 2005; Pampanelli et al., 2014; Diaz- \\
Employee Involvement & Elsayed et al., 2013; Mason et al., 2008) \\
& (Drew et al., 2004; Garza-Reyes et al., 2014; 2015; Carvalho et al., \\
Integrated Approach & 2011; Zhu and Sarkis, 2004) \\
& (Hines et al., 2004; Srivastava, 2007; Sertyesilisik, 2014; Salleh et \\
Tools and Techniques & al., 2012; Banawi and Bilec, 2014) \\
&
\end{tabular}

The remainder of the literature review will draw from the main aspects we will be exploring in our empirical study, including issues related to the implementation of green and lean practice, organisational performance, and guanxi in Chinese organisations.

\subsection{Green and lean practice and organisational performance}

Theyel (2001) points out that one of the key concerns of managers is environmental performance due to reasons ranging from contractual compliance and regulatory, to competitive advantage and public perception. However, many government bodies and organisations responsible for environmental protection programmes are generally lack of experience in the new field of environmental management and hindered by weak organisational capabilities, making it difficult, and in some cases impossible, for them to improve their overall environmental performance (Zhang and Wen, 2008; Tseng, et al., 2014b). Therefore, despite the great pressure to perform environmentally and large-scale 
investment in green programmes, these programmes cannot guarantee an improved performance of environment (Tseng et al., 2014a; Zhu and Sarkis, 2004). Recent literature offers insight into how green and lean practice can help organisations to better appreciate the notion of environmental and business performance (Dues et al., 2013; Duarte and CruzMachado, 2015; Wiengarten et al., 2013; Wadhwa, 2014; Larson and Greenwood, 2004; Sobral et al., 2013). As lean practice is an operations management approach that aims at the elimination of waste in every area of design, production, factory management and the supply network (Chauhan and Singh, 2012), its alignment with the green paradigm, and its methods and tools, seems natural (Garza-Reyes, 2015). Thus, better understanding of the relationship between environmental performance and green and lean practice is required.

The literature shows that the environmental performance can be improved by implementing green and lean practices. The evidence supporting this argument is relatively strong. First of all, researchers state that lean practices can be a catalyst for the successful implementation of green practices for improving environmental performance (Bergmiller and McCright, 2009; Dues et al., 2013; Klassen, 2000; King and Lenox, 2001; Larson and Greenwood, 2004). What is more, Garza-Reyes et al. (2015) suggest that green and lean practices can effectively work together since they are concurrent to some extent. For example, both maintain synergies related to waste reduction, lead time reduction, product design and the use of various approaches and techniques to manage people, organisations and the supply chain (Garza-Ryes et al., 2014; 2015; Dues et al., 2013; Larson and Greenwood, 2004; Wiengarten et al., 2013). Moreover, researchers such as Mollenkopf et al. (2010) and Pampanelli et al. (2014), who address the relationship between green and lean practices through different approaches to integrate them, note the advantages and synergies available when they are implemented concurrently. Furthermore, in order to measure the contribution and effect of green and lean paradigms, Carvalho et al. (2011) proposed a conceptual model that measures the relationships between green and lean practice and supply chain performance. However, research on supply chain performance indicators has gone beyond the study and development of methods to quantify their contribution to performance (GarzaRyes, 2015; Duarte and Cruz-Machado, 2014; 2015).

Besides, increased competition has encouraged many manufacturing industries to evaluate their competitive strategies and management practices with the aim of enhancing organisational performance. Therefore, researchers are starting to investigate the effect of green and lean practices on various composite dimensions of organisational performance, including different aspects of environmental, operational and financial performance and 
customer satisfaction (Dues et al., 2013; Wiengarten et al., 2013). Particularly, Rappaport (1987) points out that business performance takes into account the responsibilities and profit maximisation objectives of an organisation, while environmental performance indicates to the environmental responsibilities of an organisation (Zhu et al., 2004). Additionally, based on previous studies, business performance can be conceptualised with the two aspects of market and financial performance (Menor et al., 2007; Yang et al., 2011; Narasimhan and Kim, 2002).

This reflects the debate among researchers regarding the potential benefits of adopting green and lean practice within organisations and across supply chains. Therefore, the first hypothesis concerns whether green and lean practice can indeed improve organisational performance.

Hypothesis 1 (H1): Organisations with higher levels of adoption of green and lean practice will see greater improvements in organisational performance.

\subsection{Moderating effects of guanxi}

Thus far, the hypothesis above posits that green and lean practice is generally beneficial for environmental and business performance. According to $\mathrm{Ng}$ (2009), successful transactions in China usually follow successfully established guanxi relationships, while in Western countries a good relationship follows successful transactions. Thus, guanxi plays a vital role in Chinese organisations. The literature has already shown that there are direct relationships between guanxi and organisational performance (Wong, 2007; 2010; Cheng, 2011; Tsai et al., 2013; Yang, 2011), but the focus of the present research is more on examining whether guanxi plays a role to moderate the relationship between green and lean practices and organisational performance. Therefore, we use guanxi as a moderator in this study.

Guanxi is a key element in doing business in China. Fan (2002) explains that guanxi is considered as a basis of sustainable competitive advantage. On the one hand, guanxi is believed that can be utilised to obtain information on business opportunities, government policies and market trends (Fock and Woo, 1998). On the other hand, the guanxi network can significantly escalate business effectiveness through decreasing the cost of transactions (Fock and Woo, 1998; Davies et al., 1995). However, some studies point out that creating and preserving guanxi is a costly as well as long time-wasting undertaking and they identify it as the main hindrance of businesses (Davies et al., 1995; Yi and Ellis, 2000; Lovett et al., 1999). 
Consequently, within the modern Chinese marketplace setting, guanxi could be an efficient choice or the sole means of making things work (Yi and Ellis, 2000; Fan, 2002).

Since individuals operating in China's particular business framework are expected to be guanxi-oriented, it is important to note that the present research focused on firm-level guanxi in order to determine whether it moderates the relationship between green and lean practice and organisational performance. Firm-level networks are apparent within organisations, while inter-firm networks create links between management and government authorities (Wank, 1996). Personal relationships between firm management and governmental officials form part of the governmental guanxi network. According to Wong (2010), guanxi can be seen as a form of lubrication that eases interpersonal conflicts and can act as a buffer to problems in implementing lean practices. Thus, it is expected that, with guanxi, Chinese organisations can further increase the benefits of green and lean practice for their performance. Therefore, it is hypothesised that:

Hypothesis 2 (H2): The association between green and lean practice and organisational performance will be moderated by guanxi, such that the association will be significantly stronger when a high level of guanxi is present.

In this study, first a model was developed (Figure 1) to test the proposed positive association between green and lean practice and organisational performance as moderated by guanxi. Based on this model, the two proposed hypotheses were examined (the hypothesis 1 and hypothesis 2 are indicated by $\mathrm{H} 1$ and $\mathrm{H} 2$, respectively). The minus signs indicate negative relationships while the plus signs indicate positive relationships. The arrows mean the hypothesised relationships.

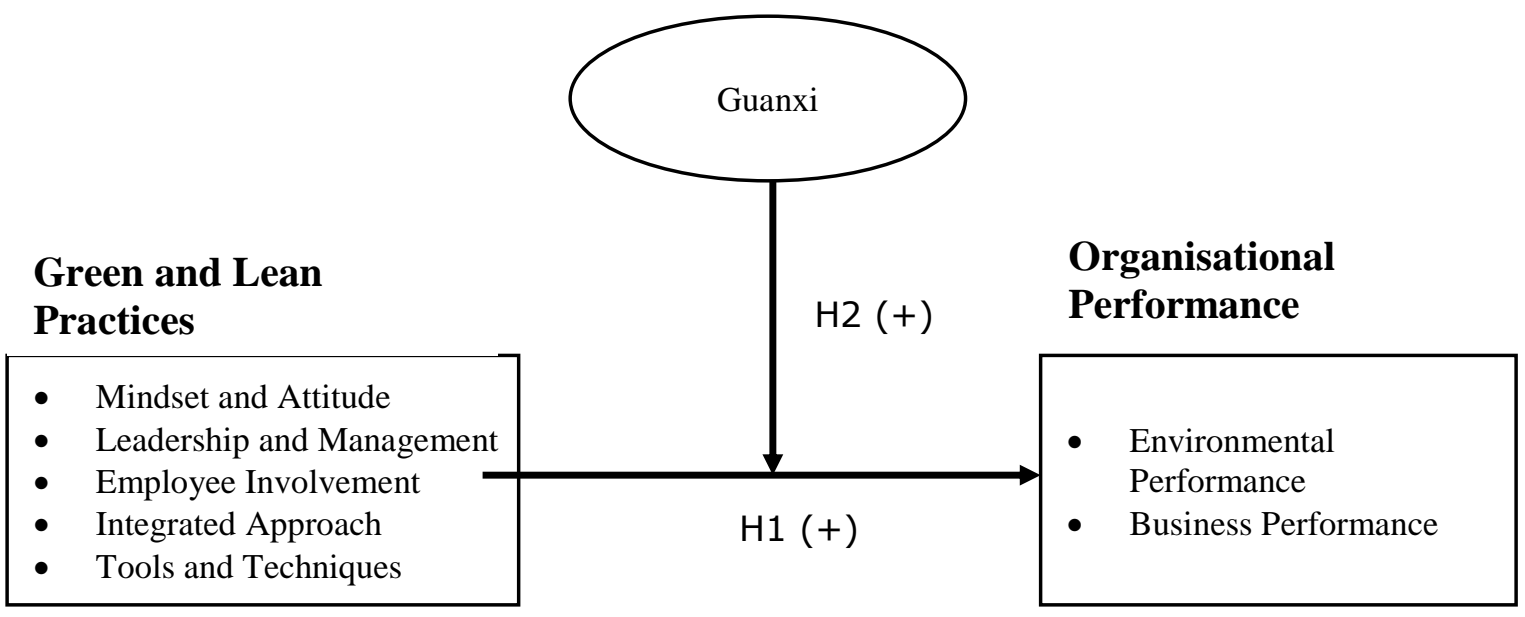


Figure 1. Proposed Research Model

\subsection{METHODOLOGY}

This section introduces the research methodology for developing the survey instrument, identifying the constructs, assessing the instrument's reliability and validity, and testing the hypothesised relationships (See Figure 1) of the proposed model.

\subsection{Development of Questionnaire}

The questionnaire was initially in English. It was then translated into Chinese by one of our Chinese researchers. The data collected consist of responses from managers in Chinese processing and manufacturing industries that have experienced the introduction of green and lean practices and seen the profound impact they can have on the organisational performance. A broad perspective on green and lean practice was identified from the literature as well as input from expert opinions.

In the study, we develop 36 items together with the corresponding constructs to be measured. Shows in Table 2, we take a broad perspective of green and lean practices, guanxi and organisational performance that play a role in supply chain management. In particular, the questionnaire had three sections: green and lean practice, guanxi utilisation; and organisational performance. The 19 items comprising the first section were developd by the author, based on a number of sources from the literature (Dues et al., 2013; Wiengarten et al., 2013; Duarte and Cruz-Machado, 2015; Sobral et al., 2013; Garza-Reyes et al., 2014; 2015; Larson and Greenwood, 2004; Mollenkopf et al., 2010; Kleindorfer et al., 2005; Pampanelli et al., 2014; Diaz-Elsayed et al., 2013; Mason et al., 2008; Kurdve et al., 2011; Carvalho et al., 2011; Cabral et al., 2012; Carvalho et al., 2014; Sertyesilisik, 2014; Salleh et al., 2012; Banawi and Bilec, 2014) and opinions from experts. Section 2 comprised 5 items developed from the literature; these items sought to capture the extent to which a firm's managers utilised guanxi connections with business community and supply chain partners (Liu et al., 2008; Cheng, 2011). There are 12 items in the third section, it was developed from the literature on environmental and business performance (Zhu et al., 2004; Zhu and Sarkis, 2004).

Table 2: Model constructs and measures

\begin{tabular}{llc}
\hline Constructs & Items & Source \\
\hline
\end{tabular}




\begin{tabular}{|c|c|}
\hline \multicolumn{2}{|c|}{ Mindset and Attitude } \\
\hline MA1 & Openness towards learning \\
\hline MA2 & Belief in the programme and confidence in its success \\
\hline MA3 & Green and lean thinking \\
\hline MA4 & Required changes in organisational culture \\
\hline \multicolumn{2}{|c|}{ Leadership and Management } \\
\hline LM1 & Dedication from senior management \\
\hline LM2 & Strong leadership \\
\hline LM3 & Clear communication of the revised vision \\
\hline LM4 & The manager's dedication to the programme's implementation \\
\hline \multicolumn{2}{|c|}{ Employee Involvement } \\
\hline EI1 & Skill and expertise \\
\hline EI2 & The dedication of the employees and resources of the entire firm \\
\hline EI3 & Working within the green and lean philosophy and principles \\
\hline EI4 & $\begin{array}{l}\text { People have to get green and lean before the organisations can get } \\
\text { green and lean }\end{array}$ \\
\hline Inte & Approach \\
\hline
\end{tabular}

Jeyaraman and

Teo, 2010;

Azevedo et al.,

2012;

Bergmiller and

McCright, 2009;

Rothenberg et al., 2001;

Florida, 1996;

Zhu et al., 2005

Drew et al., 2004;

IA1 A holistic and targeted strategy for change (it must be consistently adhered to)

IA2 Integrated green and lean operating system

Zhu and Sarkis, 2004; Carvalho et al., 2011

IA3 Use of all the goals, methods, techniques and green and lean elements in combination

Tools and Techniques

TT1 Good understanding of the green and lean tools and techniques

TT2 Selection and application of the appropriate tools and techniques

TT3 Having the right green and lean tools and techniques in place

TT4 Understanding of the organisation's processes to apply the right tools and techniques

Guanxi

GX1 Our leaders are familiar with the leaders of our partner organisations

GX2 Our leaders and the leaders of our partner organisations always invite each other to social activities

GX3 Our leaders and the leaders of our partner organisations may call on each other sometimes

GX4 Our salesmen and the staff of our partner organisations do personal favours for each other

GX5 Our salesmen and the staff of our partner organisations often communicate with each other

\section{Environmental Performance}

Kleindorfer et al.,

EP1 Reduction of air emissions

EP2 Reduction of waste water

EP3 Reduction of solid wastes

EP4 Decreased consumption of hazardous/harmful/toxic materials

EP5 Decreased in the frequency of environmental accidents

EP6 Improvement in an enterprise's environmental situation

Business Performance

2005; Zhu and

Sarkis, 2004 


\begin{tabular}{lll} 
BP1 & Sales improvement & Menor et al., \\
BP2 & Market share improvement & 2007 ; Yang et al., \\
BP3 & Efficiency of production improvement & 2011 \\
BP4 & Return on revenue improvement & \\
BP5 & Return on investment improvement & \\
BP6 & Declining debt & \\
\hline
\end{tabular}

\subsection{Data collection and sample characteristics}

The questionnaire was pilot tested on a group of managers attending a seminar. Their feedback was then collected to improve the questionnaire. The participated managers were experts in green and lean practices. Due to the difficulties in obtaining data, the data was collected from executive MBA students (Zhu and Sarkis, 2004; Chen and Tan, 2015; Zirger and Maidique, 1990). Most of them were MBA students from the authors' univeristy and were working at a wide range of organisations. In the pilot test, part questions were further clarified, making the questions easier to understand and allowing for more precise answers.

This research conducted data collection in different areas across the whole of China; one or two representative cities were chosen to collect data in each area. The two main approaches are mail through post and on-site form filling in MBA classrooms. In the first approach, surveyed organisations were selected due to the industry types and distribution of areas. The mail addresses of these organisations were acquired from Yellow Pages of China Telecom. In the second approach, in different areas several universities with MBA programmes were selected. Relevant staffs in these universities were contacted and their agreement sought prior to the survey; they were then mailed the questionnaires and information on the method of collecting data. Through these university staffs, questionnaires were sent to relevant MBA students in classrooms. The requirement was announced to students that the respondents must be working at manufacturing organisations while relating to green and lean practices and performance. The finished questionnaires were then sent back to the authors' institute.

Out of a total of 626 questionnaires administered to all the representatives and organisations, a total of 172 usable and unique replies were received. Hutcheson and Sofraniou (1999) suggested at least 150 cases sample in questionnaires. The realised sample of 172 is thus considered statistically significant. The biases associated with the pilot test and data collection were examined by dividing the total 172 participants into two groups: from the mail through post $(n=64,37.2 \%)$ and from the on-site form filling in MBA classrooms $(\mathrm{n}=108,62.8 \%)$. The distribution of participated organisations in terms of size and industry 
type was shown in Table 3. It provides a basic understanding towards the sample collected. While $9.3 \%$ of the surveyed organisations had more than 5000 employees, $25.0 \%$ had fewer than 200. This suggests that the survey covered firms of widely differing scale.

Table 3: Distribution of survey respondent organisations

\begin{tabular}{|c|c|c|c|}
\hline Category & Item & $\mathbf{N}$ & $\%$ \\
\hline \multirow[t]{6}{*}{ 1. Organisation Size } & $>5000$ employees & 16 & 9.3 \\
\hline & 3000-5000 employees & 24 & 14.0 \\
\hline & 1000-3000 employees & 57 & 33.1 \\
\hline & 200-1000 employees & 32 & 18.6 \\
\hline & $<200$ employees & 43 & 25.0 \\
\hline & Total & 172 & 100 \\
\hline \multirow[t]{9}{*}{ 2. Type of industry } & Motor assembly & 34 & 19.8 \\
\hline & Power Generation & 39 & 22.7 \\
\hline & Metal and engineering or related manufacturing & 26 & 15.1 \\
\hline & Electronics manufacturing & 23 & 13.4 \\
\hline & Chemical and related manufacturing & 9 & 5.2 \\
\hline & Family apparatus industry & 22 & 12.8 \\
\hline & Packaged food & 7 & 4.1 \\
\hline & Others & 12 & 7.0 \\
\hline & Total & 172 & 100 \\
\hline
\end{tabular}

\section{RESULTS}

Structural equation modelling (SEM) with LISREL 8.80 was applied to examine and analyse the hypothesised relationships of the research model. Within the research, SEM was employed to investigate the guanxi's impacts among a collection of developed constructs (green and lean practice). All of the constructs were determined by 3 or 4 developed items. The relations impacts were investigated through carrying out a process applied in the earlier studies (Mathieu et al., 1992; Rapp et al., 2006; Cortina et al., 2001; Lewin and Sager, 2009; Kroes and Ghosh, 2010; Cheng, 2011).

\subsection{Evaluation of the measurement model}

Before the examination, exploratory factor analysis was performed using principal axis factoring to ascertain whether our items loaded onto a common latent factor. Through the study items as well as their constructs, as illustrated in Table 2, the measurement model stipulated for the research model was discovered that it can establish the scope to which the experimental study items truly calculated their corresponding construct. The thirty-six items of the survey instrument were initially evaluated to gauge their dimensions as well as their 
measurement features. An evaluation of the eigenvalues suggested a three-factor solution that incorporated green and lean practice; organisational performance as well as guanxi.

Furthermore, the convergent validity is capable of being confirmed because every item loaded largely and significantly on their constructs. In addition, all items performed in a good manner within a confirmatory factor analysis and therefore, were reserved within the model.

The chi-square measurement model illustrates significant $\left(\chi^{2}=98.642, \mathrm{df}=60, \mathrm{p}<\right.$ 0.01), indicating a perfect fit with the result of $\left(\chi^{2} / \mathrm{df}\right)$ lesser than 2 (Bentler, 1988). To investigate the general model fit with no impacts of the sample size, alternative stand-alone fit indices less sensitive to sample size were applied. They comprised the Adjusted Goodness of Fit Index (AGFI), the Goodness of Fit Index (GFI), the Comparative Fit Index (CFI) as well as the Root Mean Square Error of Approximation (RMSEA) (Joreskog and Sorbom, 1993). Hair et al., (1998) states that an excellent model fit reveals that AGFI must be higher than the value of 0.80 , GFI approximately the value of 0.90 , CFI higher than the value of 0.9 , RMSEA lower than the value of 0.1, and RMSR lower than the value of 0.05 . The measurement model's evaluation indicates an agreeable model fit $(\mathrm{AGFI}=0.883$; $\mathrm{GFI}=0.924 ; \mathrm{CFI}=0.961 ; \mathrm{NFI}=0.940 ; \mathrm{RMSEA}=0.0433)$.

In order to evaluate the reliability of the constructs, a composite reliability (CR) was used. In the research, the CR figures are going above the recommended maximum figure of 0.8 (Hair et al., 1998). In particular, each of the figures scaled in between 0.809 and 0.884 . As per the variables of the Squared Multiple Correlations (SMC), the average variance obtained was more than 0.5 in every case. According to Joreskog and Sorbom (1993), this revealed that the variance represented by every construct was higher compared to the variance represented by measurement error. Moreover, the fit of model was supported through evaluating the discriminant validity among the constructs. Table 4 sums up the evaluation outcomes of the model.

Table 4: Assessment results of the model

\begin{tabular}{lllllll}
\hline Construct & Items & Standardized loading (Error) & T value & SMC & CR & AVE \\
\hline Green and lean & MA1 & $0.727^{* *}(0.172)$ & 7.988 & 0.604 & 0.812 & 0.631 \\
practice & MA2 & $0.812^{* *}(0.150)$ & 6.375 & 0.483 & & \\
& MA3 & $0.835^{* *}(0.304)$ & 9.445 & 0.594 & & \\
& MA4 & $0.725^{* *}(0.353)$ & 5.186 & 0.679 & & \\
& & & & & \\
& LM1 & $0.713^{* *}(0.491)$ & 7.715 & 0.617 & & \\
& LM2 & $0.855^{* *}(0.269)$ & 4.277 & 0.744 & & \\
& LM3 & $0.856^{* *}(0.267)$ & 6.923 & 0.665 & &
\end{tabular}




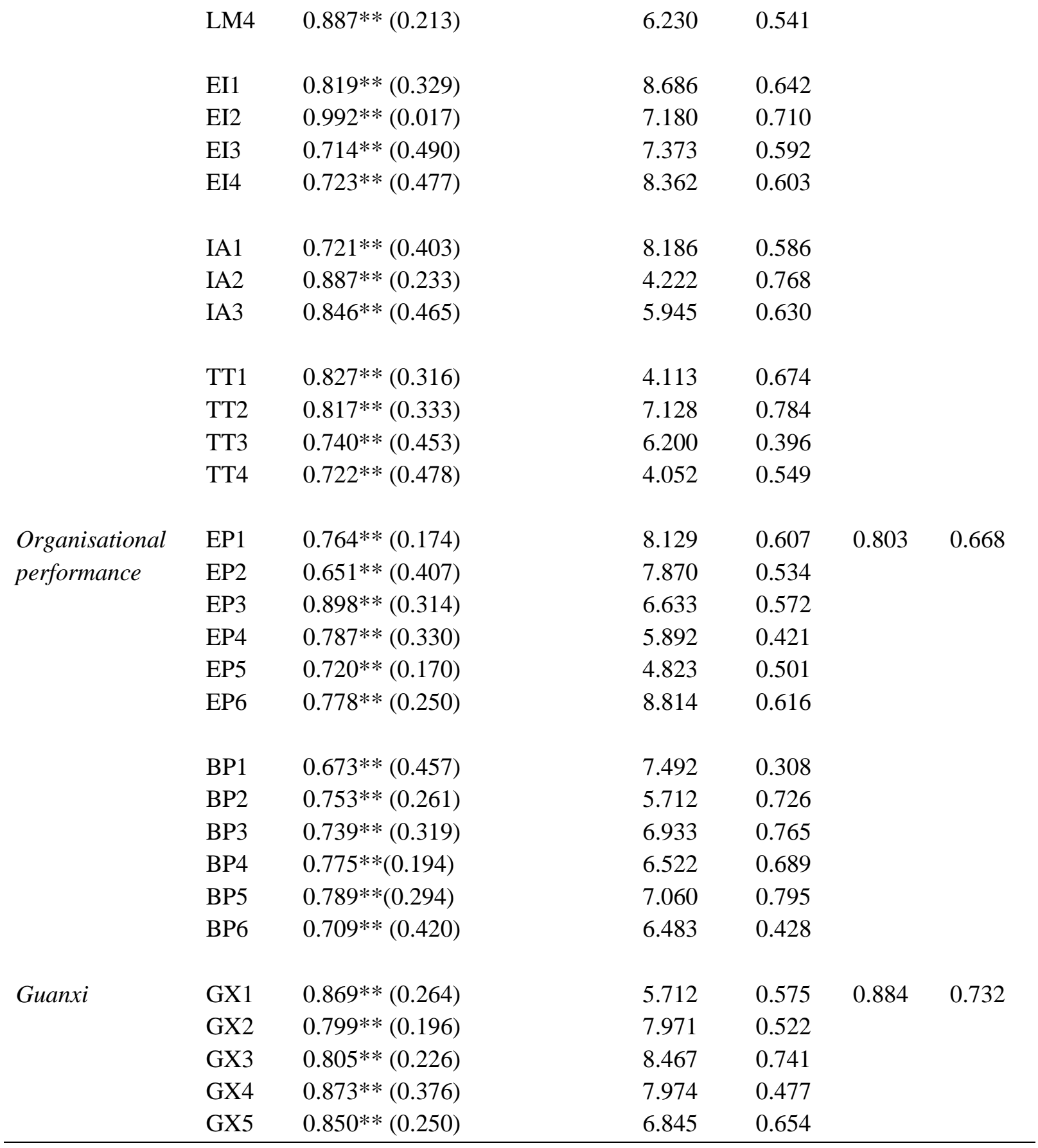

** Significant at $\mathrm{p}<0.05$.

\subsection{Evaluation of the structural model}

The inter-connections among the three constructs of the structural model are illustrated in table 5. It supports the positive relationships of the research model (see Figure 1). Green and lean practice is positively linked to organisational performance. Additionally, guanxi is positively linked to green and lean practice and organisational performance.

Because every measurement of fit attain an acceptable value $\left(\chi^{2}=149.518, \mathrm{df}=76, \mathrm{p}<0.01\right.$; 
$\mathrm{AGFI}=0.867 ; \mathrm{GFI}=0.919 ; \mathrm{CFI}=0.949 ; \mathrm{NFI}=0.934 ; \mathrm{RMSEA}=0.0474)$, the structural model's general fit is acceptable.

Table 5: Correlation matrix of constructs

\begin{tabular}{llll}
\hline Construct & $\mathbf{1}$ & $\mathbf{2}$ & $\mathbf{3}$ \\
\hline 1. Green and lean practice & 1.000 & & \\
2. Organisational performance & $0.437^{* * *}$ & 1.000 & \\
3. Guanxi & $0.442^{* * *}$ & $0.317^{* * *}$ & 1.000 \\
\hline
\end{tabular}

*** Significance at $\alpha=0.001$.

\subsection{Comparison with an alternative model}

The research followed the procedure developed by Anderson and Gerbing (1988) as well as evaluated two models (see Table 6). The initial model was the proposed model where one first-order factor (that is, the organisational performance) accounted for all the common variance among the twelve items. Within the second model, the twelve items constituted the two first-order factors (that is, the business performance as well as environmental performance).

Sequential chi-square difference tests (SCDTs) were performed so as to investigate if alternative model ought to be accepted or not. This was done through computing the disparity between the chi-square values for the alternative model and for the proposed model, with degrees of freedom equivalent to the variation in degree of freedom for the two chosen models. Table 6 exhibits the outcomes that implied the proposed model as the excellent model as per the preconditions recommended by Anderson and Gerbing (1988).

Table 6: Comparison of two models

\begin{tabular}{lll}
\hline & Proposed Model (model 1) & Alternative Model (model 2) \\
\hline$\chi^{2}(\mathrm{df})$ & $149.518(76)$ & $170.892(71)$ \\
$\chi^{2}$ difference & & 21.374 \\
df difference & 5 \\
SCDTs $(\alpha=0.05)$ & Significant \\
\hline
\end{tabular}

As a guarantee of the exclusion of the common method variance from the results, Harmon's one-factor test was employed (Podsakoff \& Organ, 1986). Un-rotated principal components examination exposed 3 factors with eigenvalues higher than one that represented a 68.9 percent of the whole variance. The initial factor did not represent most of the variance (18.4 percent). Since no single factor appeared to represent the majority of the variance, common method bias seems not to be an issue within the research. 


\subsection{Hypotheses testing}

In SEM analysis, covariance analysis inspects the relations between dependent and independent variables separately. To approximate model parameters with the co-variance matrix as data input, maximum likelihood (ML) estimation was performed. The process follows prior researches, which has been described as being well suited to theory development and testing (Kroes and Ghosh, 2010; Cheng, 2011; Anderson and Gerbing, 1988).

Table 7: Results when considering guanxi as a moderator

\begin{tabular}{lll}
\hline Independent variable & $\beta(\mathrm{t}$ value $)$ & $\beta(\mathrm{t}$ value $)$ \\
\hline Green and lean practice & $0.162^{* *}(4.330)$ & $0.221^{* * *(5.087)}$ \\
Green and lean practice x guanxi & & $0.184^{* *}(4.862)$ \\
R-squared & 0.417 & 0.573 \\
Adjusted R-squared & 0.331 & 0.452 \\
\hline
\end{tabular}

** Significance at $\alpha=0.01$.

$* * *$ Significance at $\alpha=0.001$.

The addition of the relations between the guanxi and organizational performance elevates the $\mathrm{R}^{2}$ by the value of 0.156 (see Table 7). This escalation implies that it is proper to test these relationships. Figure 2 demonstrates the model along with the hypothesised relationships, in which the solid line reveals a supported relationship. Green and lean practice $(\mathrm{H} 1: \gamma=0.221, \mathrm{t}=5.087, \mathrm{p}<0.001)$ is significantly linked to the organisational performance. Furthermore, its interaction with guanxi $(\mathrm{H} 2: \gamma=0.184, \mathrm{t}=4.862, \mathrm{p}<0.01)$ is significantly linked to organisational performance.

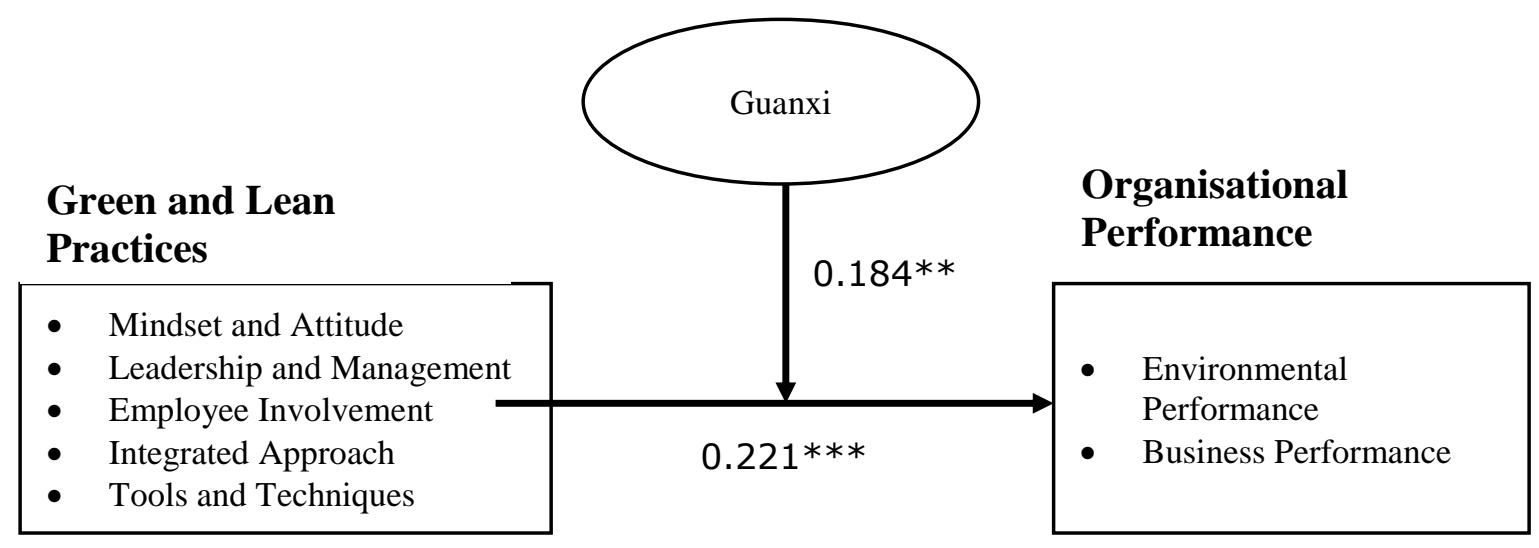

$* *$, and $* * *$ denote significance at $\alpha=0.01$ and $\alpha=0.001$, respectively.

Figure 2. The structural model 


\subsection{DISCUSSION}

Chinese organisations have a practical concern about balancing green and lean practice in supply chain management. This research clarifies how this may be done. Based on the results, the direct relationships between green and lean practice overall and environmental performances are promising. It seems to be great 'win-win' opportunities for Chinese organisations that seek to implement green and lean practice (Zhu and Sarkis, 2004). That is, business performance has a significant relationship with green and lean practice.

\subsection{Mindset and attitude}

Mindset and attitude are fundamental to green and lean success (Womack and Jones, 2003). There must be total long-term commitment to green and lean practice within the organisation. If people change how they think, then they may be inspired to do things differently and only then can the organisation hope to achieve different results. Many failed attempts to implement green and lean practice start with a fundamental misunderstanding of the concept. Clearly, the cognitive dimension is the key, and the concepts and tools must be learned, but they are not enough by themselves: many organisations have invested considerably in green and lean training programmes without ever seeing sustainable shop floor benefits. This study, though, identifies several key aspects of mindset and attitude for the successful implementation of green and lean practice, such as openness towards learning, confidence in success, as well as green and lean thinking in implementing green and lean practices.

\subsection{Leadership and Management}

Strategic commitment from leadership refers to the willingness to commit resources and continually invest in employees; and to promote a green and lean culture for continuous improvement (Al-Najem et al., 2012). Nothing dampens commitment from shop floor employees faster than leadership and management not following through their commitments to green and lean practice. Without a deep understanding of green and lean philosophy, leaders will be incapable of leading green and lean implementation and not able to create a green and lean culture. And also, managers need to ensure that the right people are in the right places, which requires an understanding of the kinds of employees that green and lean success demands. It is vital for managers to understand that there is a lot more to green and lean practice than meets the eye. We believe that leadership is also significant in green 
performance. For every highly influential manager who may have the clout to put environmental issues on the table, it takes a whole team of skilful champions working together to make green practice a reality. Making green practice happen - at a large scale and with the speed needed to reap returns on investment under these conditions, requires leadership to remix and rethink their capabilities to develop the agility and versatility they required (Rothenberg et al., 2001).

\subsection{Employee Involvement}

Zhu et al. (2005) point out that successful lean implementation can be achieved only through the efforts made by an organisation's employees. In addition, studies show that employee involvement can improve pollution control. For example, Dow Chemical has been able to reduce pollution and waste by encouraging employee involvement (Denton, 1999). This study identifies three ways in which employees can better improve their organisation's business performance and environmental performance. First of all, as a long-term approach, it requires a permanent commitment by employees. Thus, employees are required to be committed to changing the way of thinking and doing things, to continuous learning and to discipline. If people refuse to change the way they work then there is little chance of green and lean success. What is more, according to Womack and Jones (2003), very different types of skills are required from those needed in non-green and non-lean forms of organisation. It is important that employees have a deep understanding of the concepts underpinning green and lean practice - not only its tools and techniques. Human capital development is thus at the very core of green and lean practice. Employee development processes must therefore be linked to the overall green and lean transformation process. Moreover, if employees are keys to green and lean success, then it stands to reason that they should be deeply involved in all aspects of the planning and execution of green and lean practice. It is employees who continuously improve products and processes. This involvement must be genuine, and based on a deep appreciation of the fact that employees have a lot to offer. Focus should also be placed on should dispelling any distrust that employees may have of green and lean practice.

\subsection{Integrated Approach}

The key to successful green and lean practice is the integration of the two approaches (Stephan and Klassen, 2006). A green and lean integrated approach is an emerging, helpful tool to enhance organisations' business performance by creating value for customers, ensuring continuous improvement and eliminating waste as a sustainable information 
integration practice. And also, it can improve organisations' environmental performance by reducing the pollution and environmental degradation (Alshuwaikhat and Abubakar, 2008). This research builds on the need for an integrated approach, and refers to the alignment of structures and systems, which includes the behaviours and infrastructure that support green and lean practices, the integration of green and lean practice with technology, the integration of green and lean practice with other business systems and programmes, and the ability to align personnel issues with the operating system.

\subsection{Tools and Techniques}

Tools and techniques have a very important role in various types of industry in China (Srivastava, 2007; Hines et al., 2004). Implementing green and lean tools and techniques is a proven method of improving business performance and beating the competition. Some of them can additionally be used to improve an organisation's environmental performance (e.g. 'kaizen'. What is more, the United States Environmental Protection Agency (2007) introduced a toolkit that can offer lean operational managers and environmental practitioners practical techniques to improve environmental performance, reduce business costs and risk, and identify and eliminate waste. However, it is worth mentioning that lean tools and techniques do not necessarily improve environmental performance.

\subsection{Guanxi and organisational performance}

In relation to guanxi, the results suggest that it does have moderation effects between green and lean practice and organisational performance. Whether or not guanxi is utilised in a Chinese organisation has some significance in terms of supporting organisations to improve its win-win scenario. Thus, it seems to be difficult to implement green and lean practice successfully in Chinese organisations unless guanxi is in a place. In other words, utilisation of guanxi is a very important antecedent to green and lean practice, and an organisation's business and environmental performance. Indeed, a lack of guanxi may actually hurt green and lean practices and thereby overall organisational performance in Chinese organisations. Therefore, an organisation should estimate its partners carefully in order to build good guanxi networks and achieve the benefits of improved environmental and business performance. This finding indicates that a good policy in implementing green and lean practice in Chinese organisations is to establish strong and positive guanxi.

The outcomes on the effects of green and lean practice and guanxi not only are consistent with previous literature, but also identify five types of green and lean practice. In 
addition, it explores how organisational performance (environmental and business performance) is significantly affected by green and lean practice through the moderating variable guanxi.

\subsection{CONCLUSION}

In summary the following practical issues and lessons arose: (a) green and lean practice tended to have win-win relationships in terms of an organisation's environmental and business performance; (b) guanxi was a positive moderator, in that a greater extent of guanxi utilisation along with green and lean practice can lead to better organisational performance. Chinese organisations considering implementing green and lean practice could benefit greatly with good guanxi utilisation. The lessons concerning organisational relationships identified in this study should be heeded by managers. They should realise that investment in guanxi is necessary for successful the implementation of green and lean practice, which in turn will allow them to achieve better organisational performance. In order for this to happen, the policies of both governments and multinational corporations should initially encourage organisations in developing countries to further guanxi, and then aid these organisations in implementing green and lean practice.

\subsection{Research limitations and future directions}

There are limitations to the research. First of all, the data collected is based on organisations in China which were in only the very early stages of adopting green and lean practices and which had differ in many respects from organisations in different countries. The question of whether more mature green and lean adopters would generate same results, internationally, requires to be studied in the future.

Secondly, due to difficulties in data collection, the validity of this research is limited by conducting survey of MBA students. This research did not use a random sample of companies. Rather, the sample was drawn from organisations the author had an existing relationship with. Moreover, not all organisations responded to the questionnaires. These factors might also affect or limit the validity of the research findings. In addition, despite definitions and information on green and lean concepts, it may still be possible that some participants did not completely understand the questionnaires. However, this limitation is hard to overcome because different cultural and limited understanding of green and lean practice in Chinese organisations that make it hard to randomly identify and conduct surveys. 
Thirdly, the five sets of green and lean practice developed for the study (Table 1) cannot be expected to be complete or indeed precisely correct. They constitute only a limited range of researchers' and interviewees' opinions, largely based on their personal experiences. Thus, although they represent a range of perspectives, a greater number of researchers and interviewees, from more companies, could have led to a better, more concrete multivariate analysis.

Fourthly, this research only explores general relationships between green and lean practice and organisational performance. And also, it only considered environmental performance and business performance as influenced by green and lean practices. Further studies of other sectors and aspects are required and different organisational characteristics will be required to support tease out additional information on industry differences and practices.

Finally, some of the statistical significance of the moderated hierarchical regression approach may be inaccurate due to a relatively small sample size. Larger sample sizes would help to determine the true moderating effects. Given these limitations, the results of this research should be treated more as a general indication than firm evidence. However, as the main part of the empirical study supports findings reported in the literature, it is likely that the findings of this study can be broadly applied.

\section{Acknowledgement:}

This research was supported by the National Natural Science Foundation of China (NSFC) (Project Nos. 71571151 and 71371159), the National Planning Office of Philosophy and Social Science of China (Project No. 14AGL015).

\section{References:}

Abdul Wahab, A.N., Mukhtar, M., Sulaiman, R., 2013. A conceptual model of lean manufacturing dimensions. Procedia Technol. 11, 1292-1298.

AL-Najem, M., Dhakal, H.N., Bennett, N., 2012. The role of culture and leadership in lean transformation: a review and assessment model. Int. J. Lean Thinking. 3(1), 120-138.

Alshuwaikhat, H.M., Abubakar, I., 2008. An integrated approach to achieving campus sustainability: assessment of the current campus environmental management practices. J. Cleaner. Prod. 16, 1777-1785.

Anderson, J.C., Gerbing, D.W., 1988. Structural equation modelling in practice: a review and recommended two-step approach. Psychological Bulletin. 103 (3), 411-423.

Azevedo, S.G.. Carvalho, H., Duarte. S., Cruz-Machado, V., 2012. Influence of green and lean upstream supply chain management practices on business sustainability. IEEE Trans. Eng. Manag. 59(4), 753-765. 
Bai, C., Sarkis, J., Dou, Y., 2015. Corporate sustainability development in China: review and analysis. Industrial Management \& Data Systems. 115(1), 5-40.

Banawi, A., Bilec, M.M., 2014. A framework to improve construction processes: integrating lean, green and Six Sigma. Int. J. Constr. Manag. 14(1), 45-55.

Bentler, P.M., 1988. Theory and Implementation of EQS: A Structural Equations Program. Sage. Newbury Park, CA.

Bergmiller, G.G., McCright, P.R., 2009. Are lean and green programs synergistic? http://zworc.com/site/publications_assets/AreLeanAndGreenProgramsSynergistic/ (accessed on 08.09.2015).

Cabral, I., Grilo, A., Cruz-Machado, V., 2012. A decision-making model for lean, agile, resilient and green supply chain management. Int. J. Prod. Res. 50(17), 4830-4845.

Carvalho, H., Cruz-Machado, C., 2009. Integrating lean, agile, resilience and green paradigms in supply chain management. Proceedings of the third International Conference on Management Science and Engineering Management, pp. 3-14.

Carvalho, H., Duarte. S., Cruz-Machado, V., 2011. Lean, agile, resilient and green: divergences and synergies. Int. J. Lean Six Sigma. 2(2), 151-179.

Chauhan, G., Singh, T.P., 2012. Measuring parameters of lean manufacturing realization. Meas. Bus. Excell. 16(3), 57-71.

Chen, Z., Tan, K., 2013. The impact of organization ownership structure on JIT implementation and production operations performance. International Journal of Operations \& Production Management. 33(9), 1202 - 1229.

Cheng, J.H., 2011. Inter-organizational relationships and knowledge sharing in green supply chains-moderating by relational benefits and guanxi. Transportation Research Part E. 47, 837-849.

Chow, G.C. 2008. China's energy and environmental problems and policies. Journal of Accounting and Economics. 15(1), 57-70.

Cortina, J.M., Chen, G., Dunlap, W.P., 2001. Testing interaction effects in LISREL: examination and illustration of available procedures. Organisational Research Methods. 4(4), 324-360.

Davies, H., Leung, T.K., Luk, S.T., Wong, Y.H., 1995. The benefits of "Guanxi": the value of relationships in developing the Chinese market. Industrial marketing management. 24(3), 207-214.

Denton, D.K., 1999. Employee involvement, pollution control and pieces to the puzzle. Environmental Management and Health. 10(2), 105-111.

Diaz-Elsayed, N., Jondral, A., Greinacher, S., Dornfeld, D., Lanza, G., 2013. Assessment of lean and green strategies by simulation of manufacturing systems in discrete production environments. CIRP Ann. Manuf. Technol. 62(1), 475-478.

Drew, J., McCallum, B., Rogenhofer, S., 2004. Journey to lean - making operational change stick. Hampshire: Pallgrave Macmillan..

Duarte, S. and Cruz-Machado, V. 2015. Investigating lean and green supply chain linkages through a balanced scorecard framework. International Journal of Management Science and Engineering Management. 10(1), 20-29.

Duarte, S., Cruz-Machado, V. 2013. Modelling lean and green: a review from business models. The international Journal of Lean Six Sigma. 3(4), 228-250.

Dues, C.M., Tan, K.H., Lim, M., 2013. Green as the new lean: how to use lean practices as a catalyst to greening your supply chain. J. Clean. Prod. 40, 93-100.

Economy, E.C., 2007. The great leap backward? The costs of China's environmental crisis. Foreign Affairs. 86 (5), 38.

EPA (United States Environmental Protection Agency). 2007. The lean and environmental toolkit. http://www.epa.gov/lean/ (accessed on 23.09.2015). 
Fan, Y., 2002. Questioning Guanxi: Definition, Classification and Implications. International Business Review. 11 (5), 543-561.

Florida, R., 1996. Lean and green: the move to environmentally conscious manufacturing. California Management Review. 39(1), 80-105.

Fock, H.K., Woo, K.S., 1998. The China market: Strategic implications of guanxi. Business Strategy Review. 9(3), 33-43.

Fornell, C., Larcker, D.F., 1981. Evaluating structural equation models with unobservable variables and measurement error. Journal of Marketing Research. 18(1), 39-50.

Forrester, P.L., Shimizu, U.K., Soriano-Meier. H., Garza-Reyes, J.A., Cruz Basso, L.F., 2010. Lean production, market share and value creation in the agricultural machinery sector in Brazil. J. Manuf. Technol. Manag. 21(7), 853-871.

Garza-Reyes, J.A., 2015. Green lean and the need for Six sigma. Int. J. Lean Six Sigma. 6(3), 226-248.

Garza-Reyes, J.A., Parkar, H.S., Oraifige, I., Soriano-Meier, H., Harmanto, D., 2012. An empirical-exploratory study of the status of lean manufacturing in India. Int. J. Bus. Excell. 5(4), 395-412.

Gonzalez-Benito, J., 2007. A theory of purchasing's contribution to business performance. Journal of Operations Management. 25, 901-917.

Govindan, K., Azevedo, S.G., Carvalho, H., Cruz-Machodo, V. 2015. Lean, green and resilient practices influence on supply chain performance: interpretive structural modelling approach. Int. J. Environ. Sci. Technol. 12, 15-34.

Hair, J.F., Anderson, R.E., Tatham, R.L., Black, W.C., 1998. Multivariate Data Analysis with Readings, fourth ed. Prentice Hall, New Jersey.

He. G., Lu, Y., Mol, P. J., Beckers, T., 2012. Changes and Challenges: China's environmental management in transition. Environmental Development. 3(1), 25-38.

Herron, C., Hicks, C., 2008. The transfer of selected lean manufacturing techniques from Japanese automotive manufacturing into general manufacturing (UK) through change agents. Robotics and Computer-Integrated Manufacturing. 24, 524-531.

Hines, P., Holweg, M., Rich, N., 2004. Learning to evolve: a review of contemporary lean thinking. Int. J. Oper. Prod. Manag. 24(10), 994-1011.

Hutcheson, G.D., Sofroniou, N., 1999. The Multivariate Social Scientist: an introduction to generalized linear models. Sage Publications.

Jeyaraman, K., Teo, L.K., 2010. A conceptual framework for critical success factors of lean Six Sigma: implementation of the performance of electronic manufacturing service industry. 1(3), 191-215.

Joreskog, K.G., Sorbom, D., 1993. LISREL 8: Structural Equation Modeling with the SIMPLIS Command Language. Scientific Software International. Chicago.

Kao, J., 1993. The worldwide web of Chinese business. Harvard Business Review. 71(2), 2436.

King, A.A., Lenox, M.J., 2001. Lean and green? An empirical examination of the relationship between lean production and environmental performance. Prod. Oper. Manag. 10(3), 244-256.

Klassen, R.D., McLaughlin, C.P., 1996. The impact of environmental management of firm performance. Manag. Sci. 42(8), 1199-1215.

Kleindorfer, P.R., Singhal, K., Van Wassenhove, L.N., 2005. Sustainable operations management. Prod. Oper. Manag. 14(4), 482-492.

Kroes, J.R., Ghosh, S., 2010. Outsourcing congruence with competitive priorities: Impact on supply chain and firm performance. Journal of Operations Management. 28, 124-143. 
Kurdve, M., Zackrisson, M., Wiktorsson, M., Harlin, U., 2014. Lean and green integration into production system models - experiences from Swedish industry. Journal of Cleaner Production. 85, 180-190.

Larson, T., Greenwood, R., 2004. Perfect complements: synergies between lean production and eco-sustainability initiatives. Environ. Qual. Manag. 13(4), 27-36.

Lewin, J.E., Sager, K.K., 2009. An investigation of the influence of coping resources in salespersons' emotional exhaustion. Industrial Marketing Management. 38, 798-805.

Liu, Y., Yuan, L., Tao, L., Wang, Y., 2008. Relationship stability, trust and relational risk in marketing channels: evidence from China. Industrial Marketing Management. 37 (4), 432-446.

Lovett, S., Simmons, L.C., Kali, R., 1999. Guanxi versus the market: Ethics and efficiency. Journal of international business studies, pp.231-247.

Mason, R., Nieuwenhuis, P., Simons, D., 2008. Lean and green supply chain mapping: adapting a lean management tool to the needs of industrial ecology. Prog. Ind. Ecol. An Int. J. 5(4), 302-324.

Mathieu, J.E., Tannenbaum, S.I., Salas, E., 1992. Influences of individual and situational characteristics on measures of training effectiveness. Academy of Management Journal. 35 (4), 828-847.

McKinsey. 2010. The next environmental issue for business: McKinsey Global Survey results. Quarterly Aug.

Menor, L.J., Kristal, M.M., Rosenzweig, E.D., 2007. Examining the influence of operational intellectual capital on capabilities and performance. Manufacturing \& Service Operations Management. 9(4), 559-578.

Mollenkopf, D., Stolze, H., Tate, W.L., Ueltschy, M., 2010. Green, lean and global supply chain. International Journal of Physical distribution \& Logistics Management. 40(1/2), 14-41.

Muduli, K., Govindan, K., Barve, A., Kannan, D., Geng, Y., 2013. Role of behavioural factors in green supply chain management implementation in Indian mining industries. Resources, Conservation and Recycling, 76, 50-60.

Narasimhan, R., Kim, S.W., 2002. Effect of supply chain integration on the relationship between diversification and performance: evidence from Japanese and Korean firms. J. Oper. Manag. 20(3), 303-323.

Ng, E., 2009. An Empirical Investigation on the Dyad Perspective of Buyer-Seller Relationships in Australian Regional Agribusiness. Contemporary Management Research. 5 (3), 287-300.

Pakdil, F., Leonard, K.M., 2014. Dimensions for a lean organisation: development of a lean assessment tool. International Journal of Production Research. 52(15), 4587-4607.

Pampanelli, A.B., Found, P., Bernardes, A.M., 2014. A lean \& green model for a production cell. J.Clean. Prod. 85, 19-30.

Park, S.H., Luo, Y., 2001. Guanxi and organizational dynamics: Organizational networking in Chinese firms. Strategic Management Journal. 22 (5), 455- 477.

Podsakoff, P.M., Organ, D.M., 1986. Self-reports in organisational research: problems and prospects. Journal of Management. 12(4), 531-544.

Rapp, A., Ahearne, M., Mathieu, J., Schillewaert, N., 2006. The impact of knowledge and empowerment on working smart and working hard: the moderating role of experience. International Journal of Research in Marketing. 23, 279-293.

Rappaport, A., 1987. Stock market signals to managers. Harvard Business Review. 65 (6), 6376.

Rothenberg, S., Pil, F.K., Maxwell, J., 2001. Lean, green, and the quest for superior environmental performance. Prod. Oper. Manag. 10(3), 228-243. 
Salleh, N.A.M., Kasolang, S., Jaffar, A., 2012. Green lean total quality information management in Malaysian automotive companies. Procedia Eng. 41, 1708-1713.

Sertyesilisik, B., 2014. Lean and agile construction project management: as a way of reducing environmental footprint of the construction industry. Science and Engineering. 72, 179196.

Shen, L., Olfat, L., Govindan, K., Khodaverdi, R., Diabat, A. 2013. A fuzzy multi criteria approach for evaluating green supplier's performance in green supply chain with linguistic preferences. Resources, Conservation and Recycling. 74, 170-179.

Sobral, M.C., Jabbour, A.B.L.S., Jabbour, C.J.C., 2013. Green benefits from adopting lean manufacturing: a case study from the automotive sector. Environ. Qual. Manag. 22(3), 65-72.

Srivastava, S.K., 2007. Green supply-chain management: a state-of-the-art literature review. International Journal of Management Reviews. 9(1), 53-80.

Stephan V., Klassen, R.D., 2006. Extending green practices across the supply chain: The impact of upstream and downstream integration. International Journal of Operations \& Production Management. 26(7), 795 - 821.

Tan, K., Shi, L., Tseng, M. L. and Chiu, A. 2014. Managing the indirect effects of environmental regulation and performance measurement, Industrial Engineering and Management Systems 13 (2), 148-153.

Tan, R.R., Culaba, A.B., Purvis, M.R.I., Tanchuco, J.Q., 2009. Life cycle design, planning and assessment. Web-based green products life cycle management systems: reverse supply chain utilization, IGI Global, Hershey, PA, USA, pp. 1-15.

Theyel, G., 2001. Customer and supplier relations for environmental performance. Greener Management International. 35, 61-69.

Tsai, H.T., Wu, T.J., Yeh, S.P., 2013. A study of Chinese guanxi type in family business from the perspective of power-based and leadership behaviours. S. Afr. J. Econ. Manag. Sci. 16(5), 102-114.

Tseng, M. L. and Chiu, A. S. F. 2013. Evaluating firm's green supply chain management in linguistic preferences. Journal of Cleaner Production 40, 22-31.

Tseng, M. L., Lin, Y. H., Tan, K., Chen, R. H., Chen, Y. H. 2014a. Using TODIM to evaluate green supply chain management under uncertainty. Applied Mathematical Modelling 38 (11), 2983-2995.

Tseng, M.L., Tan, K., Chiu, A.S.F., 2015. Identifying the competitive determinants of firms' green supply chain capabilities under uncertainty. Clean Technologies and Environmental Policy. 1-16.

Tseng, M.L., Tan, K., Lim, M., Lin, R.J., Geng, Y., 2014b. Benchmarking eco-efficiency in green supply chain practices in uncertainty. Production Planning \& Control. 25 (13-14), 1079-1090.

Unnikrishnan, S., Hegde, D.S., 2006. Environmental training and cleaner production in Indian industry-A micro-level study. Resources, Conservation and Recycling, 50, 427-441.

Vais, A., Miron, V., Pedersen, M., Folke, J., 2005. "Lean and Green" at a Romanian secondary tissue paper and board mill-putting theory into practice. Resources, Conservation and Recycling. 46, 44-74.

Valentine, S., Godkin, L., 2001. United States expatriates in China: the impact of cultural and managerial differences. International Journal of Management. 18(4), 482-488.

Wadhwa, R. S., 2014. Synergizing lean and green for continuous improvement. Advances in Production management Systems. In: Innovative and Knowledgebased Production Management in a Global-local World. IFIP Advances in Information and Communication Technology. 439, 154-161. 
Wank, D.L., 1996. The institutional process of market clientelism: guanxi and private business in a south China city. The China Quarterly. 3, 820-838.

Wiengarten, F., Fynes, B., Onofrei, G., 2013. Exploring synergetic effects between investments in environmental and quality/lean practices in supply chains. Supply Chain Manag. An Int. J. 18(2), 148-160.

Womack, J.P., Jones, D.T., 2003. Lean Thinking Revised Edition. London: Simon \& Schuster.

Wong, M., 2007. The role of culture in implementing lean production system. Advances in Production Management Systems. 246, 413-422.

Wong, M., 2010. Guanxi Management in lean production system - an empirical study of Taiwan-Japanese Firms. The American Journal of Economics and Sociology. 69(3), 1079-1106.

Yang, F., 2011. The importance of guanxi to multinational companies in China. Asian Social Science. 7(7), 163- 168.

Yang, M.G., Hong, P., Modi, S.B., 2011. Impact of lean manufacturing and environmental management on business performance: an empirical study of manufacturing firms. Int. J. Prod. Econ. 129, 251-261.

Yi, L.M., Ellis, P., 2000. Insider-outsider perspectives of guanxi. Business Horizons. 43(1), 25-30.

Zhang, K., Wen, Z., 2008. Review and Challenges of Policies of Environmental Protection and Sustainable Development in China. Journal of Environmental Management. 88, 12491261.

Zhu Q., Sarkis, J., Geng, Y., 2005. Green supply chain management in China: drivers, practices and performance. Inter. J. Oper. Prod. Manag. 25, 449-468.

Zhu, Q., Sarkis, J., 2004. Relationships between operational practices and performance among early adopters of green supply chain management practices in Chinese manufacturing enterprises. Journal of Operations Management. 22, 265-289.

Zhu, Q., Sarkis, J., Geng, Y., 2004. Green supply chain management in China: pressures, practices and performance. International Journal of Operations and Production Management. 25(5), 449-468.

Zirger, B.J., Maidique, M.A., 1990. A model of new product development: an empirical test. Management Science 36, 867-883. 